\title{
HABITAT PREFERENCES OF THE TAWNY OWL (STRIX ALUCO) IN A SPECIAL CONSERVANCY AREA OF EASTERN SPAIN
}

\author{
ANDRÉs LÓPEZ-PEINADO ${ }^{1}$ \\ Movement Ecology Lab, Cavanilles Institute of Biodiversity and Evolutionary Biology, \\ University of Valencia, C/ Catedrático José Beltrán 2, 46980, Paterna, Valencia, Spain
}

\author{
ÁLVARO Lis \\ Laboratorio Entomología y Control de Plagas, Cavanilles Institute of Biodiversity and Evolutionary Biology, \\ University of Valencia, C/ Catedrático José Beltrán 2, 46980, Paterna, Valencia, Spain
}

\author{
Arturo M. Perona and Pascual López-López \\ Movement Ecology Lab, Cavanilles Institute of Biodiversity and Evolutionary Biology, \\ University of Valencia, C/ Catedrático José Beltrán 2, 46980, Paterna, Valencia, Spain
}

\begin{abstract}
The Tawny Owl (Strix aluco) is the most abundant nocturnal raptor in Europe. It has been thoroughly studied in various regions, but its habitat preferences in Mediterranean environments remain poorly understood. With the aim to present novel information about this aspect of the ecology of the Tawny Owl, we established 115 survey stations in the Special Conservancy Area "Sierras de Talayuelas y Aliaguilla" (Castilla-La Mancha region, eastern Spain) and carried out nocturnal surveys by recording spontaneous calls and vocal responses to call playbacks. We then assessed environmental characteristics (vegetation types, soil type, altitude, potential competitors, and anthropic disturbance) in areas where owls were detected or not detected during the breeding season. Overall, we detected 60 responding owls at 49 survey stations during breeding season in the study area (i.e., density 1.22 owls $/ \mathrm{km}^{2}$ ). We found that Tawny Owls preferred lower altitudes and patchy heterogeneous areas. Owls seemed to avoid natural grasslands and areas characterized by limestone soils and associated vegetation, and preferred areas characterized by clay soils and associated vegetation. Interestingly, we did not detect owls close to wind farms, which seem to create a buffer effect on owls' occurrence. The noise generated by the turbines might be a limiting factor that could account for this avoidance. Our multivariate results showed that Tawny Owls preferred heterogeneous patchy habitat but avoided non-irrigated arable land. Tawny Owls inhabit Mediterranean landscapes where conditions are favorable, but human activities such as wind farms may limit their distribution. Additional research is needed to determine the drivers of this avoidance and whether Tawny Owls also avoid wind farms in other regions of their range.
\end{abstract}

KeY WORDS: Tawny Owl; Strix aluco; conservation; habitat selection; Mediterranean; nocturnal raptors; owls; renewable energy; wind farms.

\section{PREFERENCIAS DE HÁBITAT DE STRIX ALUCO EN UNA ZONA DE ESPECIAL DE CONSERVACIÓN DEL ESTE DE ESPAÑA}

\begin{abstract}
RESUMEN.-Strix aluco es la rapaz nocturna más abundante en Europa. La especie ha sido extensamente estudiada en varias regiones, pero sus preferencias de hábitat en ambientes mediterráneos siguen poco estudiadas. Con el objetivo de presentar nueva información sobre este aspecto de la ecología de $S$. aluco, establecimos 115 estaciones de muestreo en la Zona Especial de Conservación "Sierras de Talayuelas y Aliaguilla" (región de Castilla-La Mancha, este de España) y realizamos muestreos nocturnos mediante el registro de llamadas espontáneas y respuestas vocales a reclamos. A continuación, evaluamos características ambientales (tipos de vegetación, naturaleza del suelo, altitud, competidores potenciales, molestias antrópicas) en áreas donde los búhos fueron detectados o no detectados durante la estación reproductora. En total, detectamos $60 \mathrm{~S}$. aluco que respondieron en 49 estaciones de muestreo durante el período
\end{abstract}

\footnotetext{
${ }^{1}$ Email address: Andres.Lopez-Peinado@uv.es
} 
reproductor en el área de estudio (i.e., densidad de 1.22 búhos $/ \mathrm{km}^{2}$ ). Encontramos que S. aluco prefirió altitudes más bajas y áreas heterogéneas en parche. Los $S$. aluco parecieron evitar los pastizales naturales y las áreas caracterizadas por suelos calizos y su vegetación asociada, mientras que prefirieron áreas caracterizadas por suelos arcillosos y su vegetación asociada. Curiosamente, no detectamos $S$. aluco cerca de parques eólicos, los cuales parecieron crear un efecto tampón en la presencia de $S$. aluco. El ruido generado por las turbinas sería un factor limitante que podría explicar esta ausencia. Nuestros resultados mostraron que $S$. aluco prefirió hábitats heterogéneos y parcheados, pero evitó los suelos de agricultura de secano. S. aluco habita paisajes mediterráneos donde las condiciones son favorables, pero las actividades humanas como los parques eólicos pueden limitar su distribución. Se necesita investigación adicional para determinar las razones de esta ausencia en los parques eólicos y si $S$. aluco también los evita en otras regiones de su área de distribución.

[Traducción de los autores editada]

\section{INTRODUCTION}

Reproduction is a critical process in which breeders generally invest a lot of energy through parental care, resulting in a trade-off between survival and reproduction (Trivers 1972, Santos and Nakagawa 2012). Organisms must select breeding territories where their biological requirements can be fulfilled. Thus, the selection of an adequate breeding territory is crucial for successful reproduction (Korpimäki 1988). However, reproduction of birds in general and raptors in particular may be threatened by different factors including predation of the adults or young (Atuo and O'Connell 2018), intraspecific and interspecific competition (Lourenço et al 2013), limited resource availability (Furness and Birkhead 1984), and direct or indirect human disturbance (Garcês et al. 2019). In order to avoid or reduce these hazards, territorial species selecting their breeding areas attend to different environmental features, including natural characteristics and human alterations. This is also the case for nocturnal raptors (Order Strigiformes), territorial birds that select and defend a breeding area in order to maximize their breeding success.

In Europe, particularly in Spain, the Tawny Owl (Strix aluco) is one of the most studied nocturnal raptors in relation to habitat selection and territory defense (Redpath 1994, 1995, Appleby and Redpath 1997, Zuberogoitia and Martínez 2000, Vrezec and Tome 2004a, 2004b, Sunde and Redpath 2006, Zuberogoitia et al. 2019, and references therein). This species shows huge niche plasticity (Vrezec and Tome 2004a). However, despite having a broad versatility in habitat selection (Marchesi et al. 2006), the Tawny Owl's presence correlates with the area of natural forests and wooded areas (Sánchez-Zapata and Calvo 1999, Bartolommei et al. 2013, Fröhlich and Ciach 2018). Tawny Owls prefer wooded areas and their edges, finding their optimal habitat in medium-sized and fragmented forests (Redpath 1995). Although there is a vast literature about this species' territory selection in Europe, most studies have been focused in non-Mediterranean areas with different environmental conditions, including vegetation (e.g., deciduous forests) and climatic conditions (i.e., Atlantic; Galeotti 1990, Redpath 1994, 1995, Appleby and Redpath 1997, Zuberogoitia and Martínez 2000, Vrezec and Tome 2004a, 2004b, Sunde and Redpath 2006, Romanowski and Żmihorski 2009, Rumbutis et al. 2017). For this reason, we here present data to fill a gap in the knowledge of the breeding ecology of this species. In this study, our aim was to explore the environmental and anthropic variables determining habitat preferences of the Tawny Owl in a Special Conservancy Area in the eastern Iberian Peninsula. We assessed the relationship between owl occurrence and habitat features in Mediterranean forests, and we discussed anthropogenic factors limiting Tawny Owl distribution in the study area.

\section{METHODS}

Study Area. We studied Tawny Owls in the Special Conservancy Area "Sierras de Talayuelas y Aliaguilla" (hereafter ZEC), which is part of the Natura 2000 network (code ES4230002). This area is located in Castilla-La Mancha region, eastern Spain (coordinates: $39^{\circ} 46.733^{\prime} \mathrm{N}, 1^{\circ} 16.150^{\prime} \mathrm{W}$; area $=115 \mathrm{~km}^{2}$; Fig. $1)$. The vegetation is primarily forest, with tree species varying depending on soil composition, which is siliceous or calcareous. On siliceous areas below 1400 masl, vast areas of maritime pine (Pinus pinaster) are interspersed with some gall oaks (Quercus faginea). Above 1400 masl, scattered Scots pines (Pinus sylvestris) and Pyrenean oaks (Quercus pyrenaica) dominate. The undergrowth consists primarily of different rockrose species (Cistus ladanifer, C. laurifolius, C. populifolius, C. salvifolius, C. clusii) and heather species (Erica arborea, E. cinerea, E. 


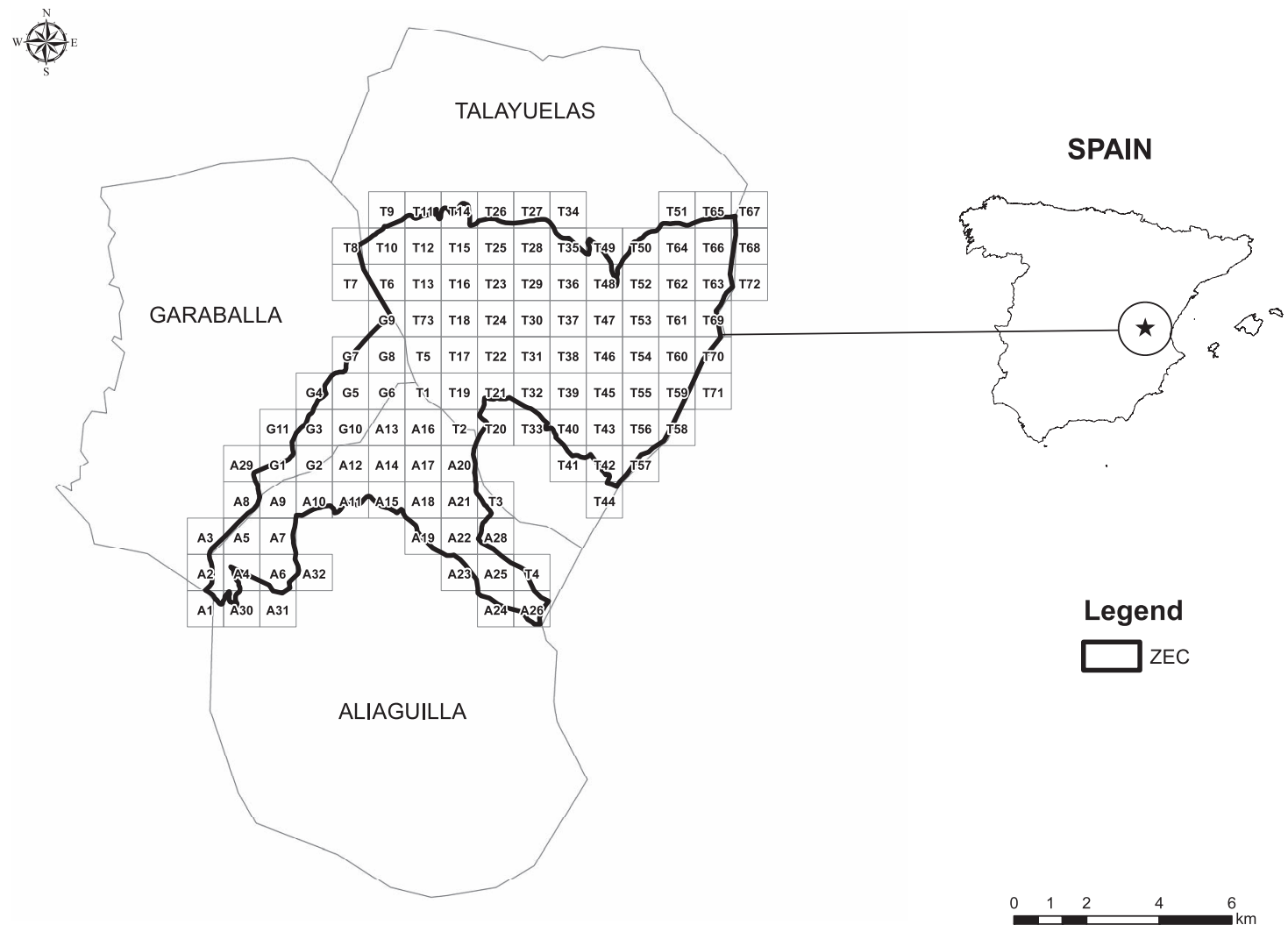

Figure 1. Location of the study area in Spain (right) and grid of $1 \mathrm{~km} \times 1 \mathrm{~km}$ squares used for surveys of Tawny Owls (left).

multiflora, and Calluna vulgaris). In contrast, in calcareous areas at lower altitudes, forests contain mainly Aleppo pines (Pinus halepensis) and holm oaks (Quercus ilex), whereas the Austrian pine (Pinus nigra) occurs at higher altitudes. The undergrowth is mainly dominated by dense shrubby kermes oaks (Quercus coccifera), accompanied by other species including sunrose (Cistus albidus), rosemary (Rosmarinus officinalis), laurustinus (Viburnum tinus), and gorses (Ulex parviflorus and Genista scorpius). Soil lithology has an important effect on water availability (Acosta et al. 2008), which is much higher in siliceous soils and very low in calcareous areas, and that, in turn, affects prey availability for owls (Torre and Arrizabalaga 2008, Rosalino et al. 2011).

In general, this area has relatively young forests, traditionally and currently dedicated to timber and resin harvest. Moreover, in this area local residents obtain other benefits from the forests, which serve as places to collect edible mushrooms and carry out apiculture, hunting, leisure activities such as hiking and climbing, and traditional low-density livestockrearing. Between wooded areas there are small open areas where non-irrigated cereals and vineyards are cultivated.

The climate is Mediterranean with continental traits, but with some maritime influence (large water accumulation due to mist). Winters are cold, with frequent frosts and eventual snows. Spring and autumn are moderately humid, but summer is dry and hot. Average annual precipitation is $587.1 \mathrm{~mm}$ and average annual temperature is $12.3^{\circ} \mathrm{C}$ (Dirección General de Montes y Espacios Naturales 2015).

Study Species. The Tawny Owl is the most abundant nocturnal raptor in Europe (König and Weick 2008). A medium-sized owl with mass around 400-600 g (König and Weick 2008), it is well-known for its strong territorial behavior and territory fidelity (Southern 1970, Hirons 1985, Sunde and Bølstad 2004). This species perches in trees while hunting 
(Mikkola 1983) and nests in cavities, other species' nests (Redpath 1995, Sunde and Redpath 2006), or occasionally on human-made structures such as buildings (Zuberogoitia 2011). The Tawny Owl consumes mostly small mammals, but also birds, amphibians, and reptiles (Cramp 1985). In our study area, Tawny Owls begin courtship and pre-breeding activities from October to January, incubation takes place between February and April, nestlings hatch between May and July, and the post-fledging period occurs from July to October.

Surveys. We divided the study area into $1 \mathrm{~km} \times 1$ $\mathrm{km}$ squares (sampling units) using the national 1$\mathrm{km}^{2}$ Universal Transverse Mercator (UTM) grid division, obtained from the Spanish National Center of Geographic Information (https://www.cnig.es/ home). We included every square containing part of the ZEC (115 squares in total). In each $1 \mathrm{~km}^{2}$ square, we established one survey station. To select each survey station's location, we followed WorthingtonHill and Conway's (2017) methodology: survey stations were located on roadways or tracks accessible by a 4-wheel-drive vehicle and as close to the center of the square as possible. Due to the dearth of suitable roadways in some squares, we excluded nine squares $(7.8 \%$ of total area) and not every station could be placed close to the center of the square. According to Zuberogoitia and Campos (1998), survey stations should be placed 500-1000 m apart in wooded and sloped mountain areas, given suitable terrain and access. At ZEC, survey stations were $>200 \mathrm{~m}$ and $<1800 \mathrm{~m}$ apart, covering all the accessible areas of the study area. We conducted surveys when wind speed was $<20 \mathrm{~km} / \mathrm{hr}$ and precipitation did not occur (Lengagne and Slater 2002, Zuberogoitia et al. 2019). We began surveys 30 min after sunset and finished by midnight.

Our survey protocol included both listening for spontaneous calls and broadcasting conspecific calls (Bibby et al. 2000, Haug and Didiuk 1993, Zuberogoitia and Campos 1998), as well as broadcasting calls of a predator species. Specifically, our survey protocol was as follows: (1) wait 5 min after arrival at the survey station (to avoid disturbance induced by researchers' vehicle), (2) listen for spontaneous Tawny Owl calls for $5 \mathrm{~min}$, (3) broadcast Tawny Owl calls for $3 \mathrm{~min}$, (4) listen for response calls of Tawny Owls for $5 \mathrm{~min}$, (5) broadcast calls of the Eurasian Eagle-Owl (Bubo bubo), a competitor and potential predator of our target species (Lourenço et al. 2013, Penteriani and Delgado 2019) for $3 \mathrm{~min}$, (6) listen for calls of both owl species for $5 \mathrm{~min}$. Total time per survey was 26 min. Every survey was performed by two researchers. Calls were broadcast from a 2018 Dacia Duster's speakers, with the vehicle's doors open. Calls were obtained from Xeno-Canto project (www.xeno-canto.org); we used the male Tawny Owl call "XC412453" and the Eurasian Eagle-Owl call "XC304909." For each survey station, we recorded the species (i.e., Tawny Owl and/or Eurasian EagleOwl), sex, and total number of owls that responded (at any point during the survey). We only recorded male calls and we assumed that every responding owl represented a breeding bird during our winterspring survey. If two or three owls responded at a single survey station from different places during a short time interval, we considered that at least two or three breeding pairs could be in the sampling unit.

Although Tawny Owls are residents and territories are maintained year-round (Southern 1970, Percival 2002), the vocal activity of the Tawny Owl varies throughout the year. According to Zuberogoitia and Martínez (2000), the best time to detect breeding territorial birds using playback calls spans from December to March in our area, but owls' spontaneous calling peaks from March to April (Zuberogoitia et al. 2019). Thus, we surveyed the entire ZEC study area twice: once in October-December (hereafter autumn) and once in February-April (hereafter winter-spring).

Habitat Characterization. Field data were mapped using ArcGIS 10.7 (Esri 2019) software with different information layers obtained from the Spanish National Institute of Geography (https://www.ign. es). We used Corine Land Cover (CLC) 2018 (https://land.copernicus.eu/) to characterize the vegetation of each square by the types of vegetation present, and the area and number of patches of each vegetation type in the area. CLC discriminates among broad vegetation categories (e.g., coniferous forest vs. mixed forest) but not among species forming these patches. Therefore, we added a lithology layer to improve our analyses, because there is a strong relationship between vegetation types and lithology (Vilà et al. 2007). We downloaded data from the National Geology Map project (Mapa Geológico Nacional, MAGNA 50; pages 637 and 665), available at the Spanish Institute of Geology and Mining (http://www.igme.es/). We simplified the information on these maps to seven broad categories of soils derived from different bedrocks: schists and shales, quartzites, conglomerates, sandstones, limestones, loams, and clays. In addition, we considered altitude of the survey 
Table 1. Variables used to characterize habitat preferences of Tawny Owls in a Special Conservancy Area of eastern Spain.

\begin{tabular}{|c|c|c|c|c|}
\hline CAtegory & VARIABLE & ABBREVIATION $^{\mathrm{a}}$ & TYPE & UNITS \\
\hline \multirow[t]{11}{*}{ Landscape } & Non-irrigated arable land & clc211 & Continuous & $\mathrm{km}^{2}$ \\
\hline & Vineyards & clc221 & Continuous & $\mathrm{km}^{2}$ \\
\hline & Complex cultivation patterns & clc242 & Continuous & $\mathrm{km}^{2}$ \\
\hline & $\begin{array}{l}\text { Land principally occupied by agriculture, with } \\
\text { significant areas of natural vegetation }\end{array}$ & clc243 & Continuous & $\mathrm{km}^{2}$ \\
\hline & Coniferous forest & clc312 & Continuous & $\mathrm{km}^{2}$ \\
\hline & Mixed forest & clc313 & Continuous & $\mathrm{km}^{2}$ \\
\hline & Natural grasslands & clc321 & Continuous & $\mathrm{km}^{2}$ \\
\hline & Sclerophylls vegetation & clc323 & Continuous & $\mathrm{km}^{2}$ \\
\hline & Transitional woodland-shrub & clc324 & Continuous & $\mathrm{km}^{2}$ \\
\hline & Number of vegetation patches per square & Patches & Continuous & $0,1,2 \ldots$ \\
\hline & Number of different CLC codes per square & Habitats & Continuous & $0,1,2 \ldots$ \\
\hline \multirow[t]{8}{*}{ Geomorphology } & Schists and shales & rcl & Continuous & $\mathrm{km}^{2}$ \\
\hline & Quartzites & rc2 & Continuous & $\mathrm{km}^{2}$ \\
\hline & Conglomerates & rc3 & Continuous & $\mathrm{km}^{2}$ \\
\hline & Sandstones & rc4 & Continuous & $\mathrm{km}^{2}$ \\
\hline & Limestones & rc5 & Continuous & $\mathrm{km}^{2}$ \\
\hline & Loams & rc6 & Continuous & $\mathrm{km}^{2}$ \\
\hline & Clays & $\mathrm{rc} 7$ & Continuous & $\mathrm{km}^{2}$ \\
\hline & Altitude & Altitude & Continuous & masl \\
\hline \multirow[t]{5}{*}{ Disturbance } & Presence/absence of paved road in the square & Road & Categorical & $0 / 1$ \\
\hline & $\begin{array}{l}\text { Presence/absence of paved road in contiguous } \\
\text { squares }\end{array}$ & Road_cont & Categorical & $0 / 1$ \\
\hline & Presence/absence of wind farms in the square & Wind-farm & Categorical & $0 / 1$ \\
\hline & $\begin{array}{l}\text { Presence/absence of wind farms in contiguous } \\
\text { squares }\end{array}$ & Wind-farm_cont & Categorical & $0 / 1$ \\
\hline & $\begin{array}{l}\text { Presence/absence of wind farms in 2-km } \\
\text { contiguous squares }\end{array}$ & Wind-farm_2_cont & Categorical & $0 / 1$ \\
\hline \multirow[t]{2}{*}{ Competition } & $\begin{array}{l}\text { Presence/absence of Eurasian Eagle-Owls in } \\
\text { the square }\end{array}$ & EEO & Categorical & $0 / 1$ \\
\hline & $\begin{array}{l}\text { Presence/absence of Eurasian Eagle-Owls in } \\
\text { contiguous squares }\end{array}$ & EOO_cont & Categorical & $0 / 1$ \\
\hline
\end{tabular}

${ }^{\mathrm{a}} \mathrm{CLC}=$ Corine Land Cover.

station, the presence of human disturbance factors (i.e., roads and wind farms), the presence/absence of potential competitors (i.e., Eurasian Eagle-Owl) in the square or in surrounding (contiguous) squares in our field survey, and habitat fragmentation measured by number of different habitat codes per square and number of different vegetation patches (Table 1).

Statistical Analysis. To analyze which variables could determine habitat preferences, we first performed nonparametric univariate tests (i.e., MannWhitney and Kruskal-Wallis) to assess differences in both detection (presence/absence) and owl density. Tawny Owl density was classified as one of three categories: "Null" (0), "Low" (one responding individual per square), or "High" (two or three individuals per square), the latter including two and three individuals to avoid the statistical bias of unbalanced groups because of the few squares with three Tawny Owls detected. We tested only the survey data we recorded during the winter-spring survey, because we assume this better represents the areas used by breeding birds.

We then fitted logistic mixed effects models (a particular case of Generalized Linear Mixed Models, GLMMs) to analyze habitat preferences using the lme4 R package (Bates et al. 2015). We grouped the variables by categories (i.e., landscape, geomorphology, disturbance, and competition; Table 1) and tested them against Tawny Owl presence/absence. The $1 \mathrm{~km} \times 1 \mathrm{~km}$ square code was included as random factor in all models. We included those variables that showed significant differences in Tawny Owl presence or absence in univariate tests 


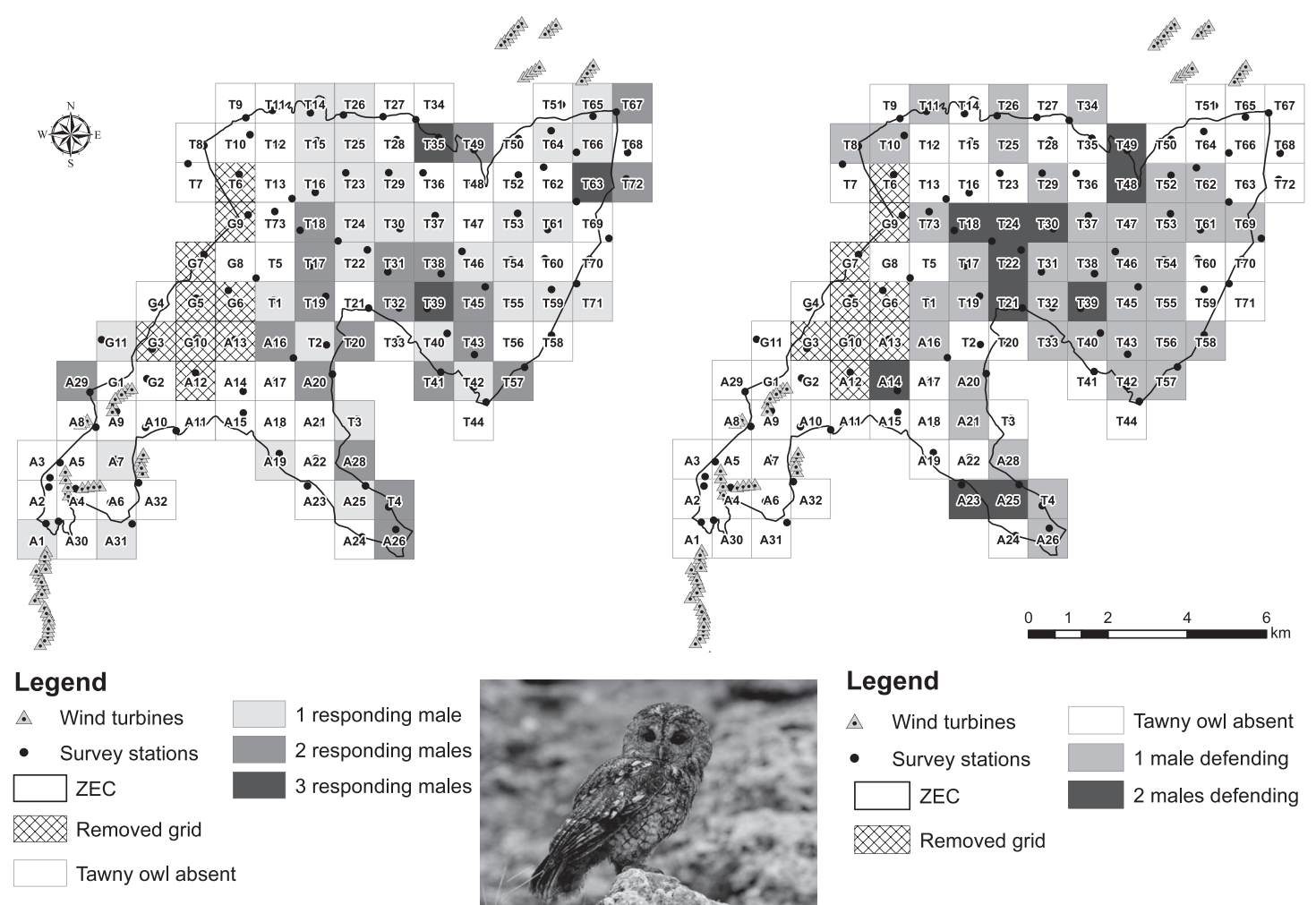

Figure 2. Distribution and abundance of the Tawny Owl in the Special Conservancy Area "Sierras de Talayuelas y Aliaguilla" (Castilla - La Mancha, eastern Spain) in autumn (left) and winter-spring (right).

and built GLMMs with them. We modelled each set of variables grouped by category separately and then the combination of all categories. We ranked models according to the Akaike Information Criterion (AIC) score (Akaike 1974). Models with $\triangle$ AIC $<2$ were considered the best models. We also computed the AIC weight $\left(\mathrm{AIC}_{w}\right)$ of each mode (Burnham and Anderson 2002). All statistical analyses were done with R version 3.6 (R Core Team 2019) and Statistica version 8.0 (StatSoft, Inc. 2007).

\section{RESUlts}

Spatial Distribution and Abundance. Overall, we surveyed 106 squares $(92.2 \%$ of the total area of the study area; Fig. 2). Our survey effort included $92 \mathrm{hr}$ of surveys. By period, we detected at least one Tawny Owl in 55 squares $(51.9 \%)$ during the autumn surveys, and in 49 squares (46.3\%) during the winter-spring surveys, a difference of $11 \%\left(\chi^{2}=\right.$ $5.611, \mathrm{df}=1, P=0.018)$. Although most of our study area was covered by forests, we did not detect Tawny Owls in many areas, and there were differences in the pattern of occupation between the autumn and winter-spring surveys (Fig. 2).

We detected 81 male Tawny Owls in 55 squares in the autumn ( 1.47 owls per sampling unit where owls were detected). Because sampling units were $1 \mathrm{~km}^{2}$, we estimated owl density as $1.47 \mathrm{owls} / \mathrm{km}^{2}$, considering only the squares where owls were detected. In the winter-spring survey, we detected fewer owls: 60 males in 49 squares (1.22 owls per sampling unit where owls were detected, or 1.22 owls $/ \mathrm{km}^{2}$ ). When we included the entire study area surveyed (106 squares), estimated densities were 0.76 owls $/ \mathrm{km}^{2}$ in autumn and 0.57 owls $/ \mathrm{km}^{2}$ in winter-spring We estimated the number of breeding pairs detected within the entire study area as 60 , based on male calls.

Using only the winter-spring information, which we assumed represents breeding habitat selection, our univariate tests with presence/absence data showed that Tawny Owls seemed to prefer lower altitudes and more fragmented areas (Table 2). Owls avoided natural grassland and areas with limestone 
Table 2. Univariate comparison of $1 \mathrm{~km} \times 1 \mathrm{~km}$ squares where Tawny Owls were detected or not detected in the study area during the winter-spring survey. Significant variables are highlighted in bold. Variables defined in Table 1.

\begin{tabular}{|c|c|c|c|}
\hline VARIABLE TyPE & $\begin{array}{c}\text { VARIABLE } \\
\text { ABBREVIATION }\end{array}$ & Statistic & $P$-Value \\
\hline \multirow[t]{11}{*}{ Landscape } & clc211 & 1271.5 & 0.365 \\
\hline & clc221 & 1305.0 & 0.233 \\
\hline & clc242 & 1342.0 & 0.548 \\
\hline & clc243 & 1359.5 & 0.674 \\
\hline & clc312 & 1328.0 & 0.666 \\
\hline & clc313 & 1349.0 & 0.736 \\
\hline & clc321 & 1711.5 & 0.022 \\
\hline & clc323 & 1344.5 & 0.708 \\
\hline & clc324 & 1177.0 & 0.153 \\
\hline & Patches & 980.0 & 0.007 \\
\hline & Habitats & 1106.0 & 0.062 \\
\hline \multirow[t]{8}{*}{ Geomorphology } & $\mathrm{rc1}$ & 1276.0 & 0.255 \\
\hline & $\mathrm{rc} 2$ & 1367.5 & 0.805 \\
\hline & rc3 & 1169.0 & 0.091 \\
\hline & rc4 & 1593.0 & 0.207 \\
\hline & rc5 & 1952.0 & $<\mathbf{0 . 0 0 1}$ \\
\hline & rc6 & 1507.0 & 0.460 \\
\hline & rc7 & 702.0 & $<0.001$ \\
\hline & Altitude & 2073.5 & $<\mathbf{0 . 0 0 1}$ \\
\hline \multirow[t]{5}{*}{ Disturbance } & Road & 4.789 & 0.029 \\
\hline & Road_cont & 11.628 & $<0.001$ \\
\hline & Wind-farm & 6.382 & 0.012 \\
\hline & Wind-farm_cont & 20.991 & $<\mathbf{0 . 0 0 1}$ \\
\hline & Wind-farm_2_cont & 29.336 & $<0.001$ \\
\hline \multirow[t]{2}{*}{ Competition } & EEO & 0.405 & 0.524 \\
\hline & EOO_cont & 1.040 & 0.308 \\
\hline
\end{tabular}

soils, but preferred areas with clay soils (Table 2). Relative to human disturbance, Tawny Owls avoided areas of wind farms. There were significant differences between squares with and without owl detections in all three related wind-farm variables: wind-farm presence/absence in the square, in the contiguous squares, and in the $2-\mathrm{km}$ contiguous squares (Table 2). We found a positive relationship between roads and Tawny Owl occurrence in two related variables: road presence/absence within the square and within the contiguous squares (Table 2). In relation to potential competitors, we detected eagle-owls at seven and two sampling units in autumn and winter-spring, respectively. Interestingly, in all sampling units where eagle-owls were detected, Tawny Owls were detected as well.

In winter-spring surveys, Tawny Owls were detected at higher numbers at lower altitude (nonparametric univariate tests; $\mathrm{H}_{2,106}=18.424, P=0.001$ ) with clay $\left(\mathrm{H}_{2,106}=23.342, P<0.001\right)$ and limestone soils $\left(\mathrm{H}_{2,106}=13.957, P=0.001\right)$, and in heterogeneous $\left(\mathrm{H}_{2,106}=7.720, P=0.021\right)$ and fragmented environments $\left(\mathrm{H}_{2,106}=8.528, P=0.014\right)$.

The best model to account for habitat preferences was the one that included geomorphology, landscape, and disturbance variables (Table 3). This model explained $74.5 \%$ of the total variance. However, the only significant predictors were two landscape features: Tawny Owls preferred areas with many vegetation patches and avoided non-irrigated arable lands (Table 4).

\section{DISCUSSION}

Our study showed the importance of environmental factors and human disturbance for habitat selection of the Tawny Owl in Mediterranean landscapes. We found that vegetation, soil nature, altitude, environmental heterogeneity, and disturbance caused by human infrastructure helped explain the distribution and abundance of the Tawny Owl in our study area. The role of wind farms may be important, reducing the available area for

Table 3. Model selection results of the logistic mixed effects models of Tawny Owl's habitat preferences during the winter-spring survey ranked according to AIC values. Abbreviations: $\mathrm{df}=$ degrees of freedom, $\operatorname{LogLik}=\log$ likelihood, AIC $=$ Akaike information criterion; $\mathrm{AIC}_{\mathrm{w}}=$ Akaike weight.

\begin{tabular}{lrrrrr}
\hline \multicolumn{1}{c}{ MoDEL } & DF & LOGLIK & AIC & $\Delta$ AIC $^{*}$ AIC $_{\mathrm{W}}$ \\
\hline Geomorphology + Landscape + Disturbance & 16 & -37.239 & 106.478 & 0.000 & 0.859 \\
Landscape + Disturbance & 11 & -44.269 & 110.538 & 4.061 & 0.113 \\
Geomorphology + Landscape & 11 & -45.731 & 113.462 & 6.985 & 0.026 \\
Disturbance & 7 & -52.216 & 118.433 & 11.955 & 0.002 \\
Geomorphology + Disturbance & 12 & -49.258 & 122.516 & 16.038 & 0.000 \\
Landscape & 6 & -61.496 & 134.993 & 28.515 & 0.000 \\
Geomorphology & 7 & -60.910 & 135.821 & 29.343 & 0.000 \\
Null model & 2 & -73.171 & 150.343 & 43.865 & 0.000 \\
\hline
\end{tabular}


Table 4. Results of the best logistic mixed effects model of habitat preferences of the Tawny Owl in eastern Spain during the winter-spring survey. The model included geomorphology, landscape features, and disturbance as dependent factors. Significant predictors are highlighted in bold.

\begin{tabular}{|c|c|c|c|c|}
\hline VARIABLE & Estimate & STD. ERROR & $Z$ & $P$-value \\
\hline (Intercept) & 2.087 & 4.181 & 0.499 & 0.618 \\
\hline Conglomerates & -4.216 & 2.504 & -1.684 & 0.092 \\
\hline Sandstones & -0.100 & 1.276 & -0.078 & 0.938 \\
\hline Limestone & -1.969 & 1.705 & -1.155 & 0.248 \\
\hline Clays & 1.233 & 1.529 & 0.806 & 0.420 \\
\hline Altitude & -0.004 & 0.004 & -1.008 & 0.313 \\
\hline Habitats & -0.119 & 0.316 & -0.376 & 0.707 \\
\hline Patches & 1.086 & 0.545 & 1.993 & 0.046 \\
\hline Non-irrigated arable land & -8.447 & 2.714 & -3.112 & 0.002 \\
\hline Natural grasslands & -6.854 & 3.899 & -1.758 & 0.079 \\
\hline Road & -0.761 & 1.017 & -0.748 & 0.454 \\
\hline Contiguous road & 1.058 & 0.865 & 1.223 & 0.221 \\
\hline Wind farm & -6.096 & 2518689.829 & 0.000 & 1.000 \\
\hline Contiguous wind farm & 2.363 & 340830.828 & 0.000 & 1.000 \\
\hline 2-km contiguous wind farm & -27.509 & 330238.704 & 0.000 & 1.000 \\
\hline
\end{tabular}

this species as a consequence of a potential buffer effect (Pearce-Higgins et al. 2009).

Spatial Distribution and Abundance. In contrast to previous studies that showed the Tawny Owl is most vocal during incubation (Zuberogoitia et al. 2019), we found a slight decrease in the number of owls detected during the winter-spring surveys in comparison to the autumn surveys. Two potential explanations could account for these results. In autumn, adult males (that may eventually breed) and young males (floaters) may call or respond to call broadcasts, but by winter-spring, the floaters may no longer respond (Appleby and Redpath 1997). In addition, Tawny Owls' nonbreeding-season territories are $50 \%$ larger than breeding-season territories (Sunde et al. 2001), so individual birds in our study may respond from more blocks in the autumn and fewer by winter-spring when territories contract. Furthermore, considering the territorial nature of the Tawny Owl (Redpath 1994), intraspecific competition between males to defend the territories could lead to the expelling of subordinate males, thus decreasing the average density found in the winter-spring survey in comparison to the autumn survey.

The breeding season population density we estimated $\left(0.57\right.$ pairs per $\mathrm{km}^{2}$ in the entire study area and 1.22 pairs per $\mathrm{km}^{2}$ within the squares where owls were detected) was relatively low in comparison to the mean densities (between 0.2 and 5 pairs per $\mathrm{km}^{2}$ ) reported by other authors in Europe (South- ern 1970, Galeotti 1994, Galeotti and Pavan 1993, Hirons 1985, Redpath 1994, Jedrzejewski et al. 1996, Sánchez-Zapata and Calvo 1999). Several factors may influence this. First, we surveyed each sampling unit only one time in autumn and one time in winterspring, and did not search for nests or determine detectability, so it is likely that we did not detect all owls in our study area. In addition, this species' reproductive rate varies with the abundance of cyclic microtid rodents, such that its reproductive rate is low in one of every three years (Francis and Saurola 2004); if our one-year study was conducted in a year of low rodent abundance, then detection of owls calling or responding to playbacks might also have been low.

Habitat Preferences. Our results both of the univariate comparisons and the GLMMs showed that Tawny Owls preferred areas at lower altitude, with greater habitat fragmentation, non-irrigated arable lands, and areas without natural pastures (as observed by Brambilla et al. 2020) on clay soils. According to Vrezec and Tome (2004b), the Tawny Owl in central Slovenia has no altitude limitations for breeding territories, and when it avoids higherelevation study areas it is due to competitive exclusion by other larger nocturnal raptors such as the Eurasian Eagle-Owl. In our study area, we did not find an effect of Ural Owl (Strix uralensis) occurrence on Tawny Owl distribution; however, we detected few eagle-owls overall. Other factors might keep the Tawny Owl from inhabiting higher altitudes, such as 
the lower height of the vegetation, the presence of wind turbines (all of which are placed along the top of mountain ridges), or lower temperatures, which may affect prey availability. For example, in the Duna-Ipoly National Park (Hungary), Tawny Owls select higher elevations, but this study was done at lower elevations (Sasvári and Hegyi 2011). In our case, our results showed a selection of intermediate conditions, either because of the vegetation of those areas and/or less human disturbance.

In our study area, Tawny Owls were detected in areas with higher heterogeneity of vegetation types (i.e., based on the different codes of the CLC) and more ecotones. This result is consistent with Fröhlich and Ciach (2019) who found that environmental heterogeneity and habitat fragmentation are characteristics that maximize the richness of niches for different micromammals and increase food availability, thus increasing the diversity of owls and their abundance. Moreover, Tawny Owl detection was low in areas with natural pastures. This was an expected result considering that this species needs trees for hunting and breeding, and that open areas could represent low-quality hunting habitats (Redpath 1995, Sunde and Redpath 2006). In addition, other studies showed that Tawny Owl diet is more diverse in forest areas (Romanowski and Żmihorski 2009). Therefore, it seems that large grassland areas could prevent Tawny Owls from establishing territories.

Because of the correlation between vegetation and lithology, we concluded that owls avoided Aleppo pine forests (on limestone soils) and preferred maritime pine forests (on siliceous soils). Avoidance may be driven by different factors, such as differences in vegetation associated with water availability in each soil type and its impact on the corresponding micromammal community (e.g., a reduced availability of adequate substrates for burrows or shelters). If the vegetation of limestone areas is less favorable for prey, this could have an indirect effect on the Tawny Owl. This could also have other effects in terms of fewer suitable nesting spots, or the occurrence of other species that may compete for resources (e.g., forest raptors that prefer limestone areas; e.g., Brambilla et al. 2020). In our study area, dense shrubby kermes oaks on limestone soils cover large areas and likely reduce hunting areas for the Tawny Owl.

We found evidence that the presence of wind turbines negatively affects Tawny Owl presence during the breeding season in a radius of up to 2 $\mathrm{km}$, at least in our univariate comparisons. Windfarm management considers the lethal effect of turbines, but does not consider indirect effects, including negative buffer effects (Pearce-Higgins et al. 2009), noise disturbance (Madders and Whitfield 2006), and changes in the landscape (Beston et al. 2016). Noise can disturb animal communication by reducing the receiver's ability to capture important information as background noise increases, a process termed "acoustic masking" (Francis et al. 2011). This acoustic masking could reduce the success of owls attempting to find a mate and establish a territory (Bayne et al. 2008, Francis et al. 2009, Francis and Barber 2013, Shannon et al. 2016, Shonfield and Bayne 2017). In addition, the effect of noise on nocturnal predators decreases hunting success by reducing their chance of detecting prey (Mason et al. 2016, Ciach and Fröhlich 2017, Fröhlich and Ciach 2018). This buffer effect could explain the avoidance of the area around wind farms and may agree with other studies in which anthropogenic noise affects animal behavior, distribution, and reproductive success (Francis and Barber 2013).

In addition, the installation of wind turbines also entails changes in the landscape such as increased erosion and drying of the areas in which wind turbines are located (Beston et al. 2016), causing a loss of plant cover. This effect could be transferred to the Tawny Owl via the food web, by decreasing prey availability. The Tawny Owl feeds mainly on micromammals (Cramp 1985), which are closely linked to the plant cover in the undergrowth. Hence, a decrease in the herbaceous canopy could lead to a significant reduction in the abundance and diversity of these prey.

We also found a significant relationship between the presence of roads in a square or the neighboring ones and the occurrence of Tawny Owl, at least in our univariate comparisons. However, it is curious that this relationship was positive. This positive relationship was counterintuitive given the negative effects of roads relative to noise disturbance (Gomes et al. 2009, Hindmarch et al. 2012, Silva et al. 2012, McClure et al. 2013, Senzaki et al. 2016), pollutants, and collisions with vehicles (Fahrig and Rytwinski 2009). Traffic noise can reduce hunting efficiency of nocturnal raptors (Senzaki et al. 2016). Roads modify behavior and reduce the connectivity of populations in some nocturnal birds (Grilo et al. 2014) and road habitats may represent poorer quality areas for owls (Silva et al. 2012). Our results 
might be explained by the small sample size (17 squares with presence of road and 21 with roads in the neighboring square), together with the presence of favorable areas (low altitude, high heterogeneity, and clay soils) in the vicinity of the road, and very low vehicle traffic at night. In addition, there may be a link between roads and associated areas for rest and recreation where drivers stop to eat; in these areas, the accumulation of organic waste could enhance the populations of micromammals and, consequently, their predators too.

Conclusions. Our results show that Tawny Owls prefer lower-altitude areas of higher habitat heterogeneity during the breeding season. Owls were not detected in large areas surrounding wind turbines, potentially because of noise disturbance or reduced prey populations, but this needs more study. Given the important role of habitat characteristics on owl presence, we recommend that managers and developers consider the avoidance effect caused by wind farms in future planning of power infrastructure in Mediterranean ecosystems in order to avoid negative effects on owls.

\section{ACKNOWLEDGMENTS}

We thank Andrés López Sánchez and Berta Peinado Ramírez for funding the project and collaborating in fieldwork. We also thank the forest ranger Manuel C. Arco Martos for his selfless collaboration. Robby Drechsler helped in translating a preliminary draft of the paper. Finally, we thank the Provincial Direction of Agriculture, Environment and Rural Development of Cuenca, especially Nuria Cardo Maeso and Enrique Montero Verde, for their willingness and interest with this work. C. Dykstra, I. Zuberogoitia, and two anonymous reviewers made valuable comments that improved the original manuscript.

\section{Literature Cited}

Acosta, B., L. Sánchez-Jardón, A. del Pozo, E. García-Ibáñez, M. A. Casado, J. Montalvo, and F. D. Pineda (2008). Grassland species composition and morpho-functional traits along an altitudinal gradient in a Mediterranean environment: Relationship with soil water availability and evaporative dynamic. Acta Oecologica 34:26-37.

Akaike, H. (1974). A new look at the statistical model identification. IEEE Transactions on Automatic Control 19:716-723.

Appleby, B. M., and S. M. Redpath (1997). Variation in the male territorial hoot of the Tawny Owl Strix aluco in three English populations. Ibis 139:152-158.

Atuo, F. A., and T. J. O'Connell (2018). Superpredator proximity and landscape characteristics alters nest site selection and breeding success of a subordinate predator. Oecologia 186:817-829.
Bartolommei, P., A. Mortelliti, F. Pezzo, and L. Puglisi (2013). Distribution of nocturnal birds (Strigiformes and Caprimulgidae) in relation to land-use types, extent and configuration in agricultural landscapes of central Italy. Rendiconti Lincei 24:13-21.

Bates, D., M. Maechler, B. Bolker, S. Walker, R. H. B. Christensen, H. Singmann, B. Dai, F. Scheipl, G. Grothendieck, P. Green, and J. Fox (2015). Package 'Ime4'. Convergence 12:2. https://github.com/lme4/ lme4/.

Bayne, E. M., L. Habib, and S. Boutin (2008). Impacts of chronic anthropogenic noise from energy-sector activity on abundance of songbirds in the boreal forest. Conservation Biology 22:1186-1193.

Beston, J. A., J. E. Diffendorfer, S. R. Loss, and D. H. Johnson (2016). Prioritizing avian species for their risk of population-level consequences from wind energy development. PLoS ONE 11:e0150813. https://doi. org/10.1371/journal.pone.0150813.

Bibby, C. J., N. D. Burgess, D. A. Hill, and S. Mustoe (2000). Bird Census Techniques. Academic Press, London, UK.

Brambilla, M., D. Scridel, G. Bazzi, L. Ilahiane, A. Iemma, P. Pedrini, E. Bassi, R. Bionda, L. Marchesi, F. Genero, and N. Teufelbauer (2020). Species interactions and climate change: How the disruption of species co-occurrence will impact on an avian forest guild. Global Change Biology 26:1212-1224.

Burnham, K., and D. Anderson (2002). Model Selection and Multi-model Inference. Springer, Berlin, Germany.

Ciach, M., and A. Fröhlich (2017). Habitat type, food resources, noise and light pollution explain the species composition, abundance and stability of a winter bird assemblage in an urban environment. Urban Ecosystems 20:547-559.

Cramp, S. (1985). Tawny Owl Strix aluco. In The Birds of the Western Palearctic (K. E. L. Simmons, R. Gillmor, P. A. D. Hollom, R. Hudson, E. M. Nicholson, M. A. Ogilvie, P. J. S. Olney, C. S. Roselaar, K. H. Voous, D. I. M. Wallace, and J. Wattel, Editors). Oxford University Press, Oxford, UK. pp. 526-546.

Dirección General de Montes y Espacios Naturales (2015). Plan de Gestión "Sierras de Talayuelas y Aliaguilla" ES4230002 (Cuenca). Documento 1. Diagnóstico del espacio Natura 2000. Dirección General de Montes y Espacios Naturales, Consejería de Agricultura, Junta de Comunidades de Castilla-La Mancha, Toledo, Spain.

Esri (2019). ArcGIS Desktop: Release 10.7.1 Environmental Systems Research Institute, Redlands, CA, USA.

Fahrig, L., and T. Rytwinski (2009). Effects of roads on animal abundance: an empirical review and synthesis. Ecology and Society 14:1-21.

Francis, C. D., and J. R. Barber (2013). A framework for understanding noise impacts on wildlife: An urgent conservation priority. Frontiers in Ecology and Environment 11:305-313.

Francis, C. D., C. P. Ortega, and A. Cruz (2009). Noise pollution changes avian communities and species interactions. Current Biology 19:1415-1419. 
Francis, C. D., C. P. Ortega, and A. Cruz (2011). Noise pollution filters bird communities based on vocal frequency. PloS ONE 6:e27052. https://doi.org/10. 1371/journal.pone.0027052.

Francis, C. M., and P. Saurola (2004). Estimating components of variance in demographic parameters of Tawny Owls, Strix aluco. Animal Biodiversity and Conservation 27:489-502.

Fröhlich, A., and M. Ciach (2018). Noise shapes the distribution pattern of an acoustic predator. Current Zoology 64:575-583.

Fröhlich, A., and M. Ciach (2019). Nocturnal noise and habitat homogeneity limit species richness of owls in an urban environment. Environmental Science and Pollution Research 26:17284-17291.

Furness, R. W., and T. R. Birkhead (1984). Seabird colony distributions suggest competition for food supplies during the breeding season. Nature 311:655-656.

Galeotti, P. (1990). Territorial behaviour and habitat selection in an urban population of the Tawny Owl Strix aluco L. Bolletino di Zoologia 57:59-66.

Galeotti, P. (1994). Patterns of territory size and defence level in rural and urban Tawny Owl (Strix aluco) populations. Journal of Zoology 234:641-658.

Galeotti, P. (1998). Correlates of hoot rate and structure in male Tawny Owls Strix aluco: Implications for male rivalry and female mate choice. Journal of Avian Biology 29:25-32.

Galeotti, P., and G. Pavan (1993). Differential responses of territorial Tawny Owls Strix aluco to the hooting of neighbours and strangers. Ibis 135:300-304.

Garcês, A., I. Pires, F. A. L. Pacheco, L. F. Sanches Fernandes, V. Soeiro, S. Lóio, J. Prada, R. Cortes, and F. L. Queiroga (2019). Preservation of wild bird species in northern Portugal: Effects of anthropogenic pressures in wild bird populations (2008-2017). Science of the Total Environment 650:2996-3006.

Gomes, L., C. Grilo, C. Silva, and A. Mira. (2009). Identification methods and deterministic factors of owl roadkill hotspot locations in Mediterranean landscapes. Ecological Research 24:355-370.

Grilo, C., D. Reto, J. Filipe, F. Ascensão, and E. Revilla (2014). Understanding the mechanisms behind road effects: Linking occurrence with road mortality in owls. Animal Conservation 17:555-564.

Haug, E., and A. Didiuk (1993). Use of recorded calls to detect Burrowing Owls. Journal of Field Ornithology 64:188-194.

Hindmarch, S., E. A. Krebs, J. E. Elliott, and D. J. Green (2012). Do landscape features predict the presence of Barn Owls in a changing agricultural landscape? Landscape and Urban Planning 107:255-262.

Hirons, G. J. M. (1985). The effects of territorial behaviour on the stability and dispersión of Tawny Owl (Strix aluco) populations. Journal of Zoology 1:21-48.

Jedrzejewski, W., B. Jedrzejewska, A. Szymura, and K. Zub (1996). Tawny Owl (Strix aluco) predation in a pristine deciduous forest (Bialowieza National Park, Poland). Journal of Animal Ecology 65:105-120.

König, C., and Weick, F. (2008). Owls of the World. A\&C Black, London, UK.

Korpimäki, E. (1988). Effects of territory quality on occupancy, breeding performance and breeding dispersal in Tengmalm's Owl. Journal of Animal Ecology 57:97-108

Lengagne, T., and P. J. B. Slater (2002). The effects of rain on acoustic communication: Tawny Owls have good reason for calling less in wet weather. Proceedings of the Royal Society B: Biological Sciences 269:2121-2125.

Lourenço, R., F. Goytre, M. del Mar Delgado, M. Thornton, J. E. Rabaça, and V. Penteriani (2013). Tawny Owl vocal activity is constrained by predation risk. Journal of Avian Biology 44:461-468.

Madders, M., and D. P. Whitfield (2006). Upland raptors and the assessment of wind farm impacts. Ibis 148:4356.

Marchesi, L., F. Sergio, and P. Pedrini (2006). Implications of temporal changes in forest dynamics on density, nestsite selection, diet and productivity of Tawny Owls Strix aluco in the Alps. Bird Study 53:310-318.

Mason, J. T., C. J. W. McClure, and J. R. Barber (2016). Anthropogenic noise impairs owl hunting behavior. Biological Conservation 199:29-32.

McClure C. J. W., H. E. Ware, J. Carlisle, G. Kaltenecker, and J. R. Barber (2013). An experimental investigation into the effects of traffic noise on distributions of birds: Avoiding the phantom road. Proceedings of the Royal Society B: Biological Science 280:2013-2290.

Mikkola, H. (1983). The Owls of Europe. T. and A. D. Poyser, Calton. UK.

Pearce-Higgins, J. W., L. Stephen, R. H. Langston, I. P. Bainbridge, and R. Bullman (2009). The distribution of breeding birds around upland wind farms. Journal of Applied Ecology 46:1323-1331.

Penteriani, V., and M. del Mar Delgado. (2019). The Eagle Owl. Bloomsbury Publishing, London, UK.

Percival, S. M. (2002). Tawny Owl Strix aluco. In The Migration Atlas: Movements of the Birds of Britain and Ireland (C. Wernham, M. Toms, J. Marchant, J. Clark, G. Siriwardena, and S. Baillie, Editors). T. and A. D. Poyser, Calton, UK. pp. 432-433.

R Core Team (2019). R: A language and environment for statistical computing. R Foundation for Statistical Computing, Vienna, Austria. https://www.R-project. org/.

Redpath, S. M. (1994). Censusing Tawny Owls Strix aluco by the use of imitation calls. Bird Study 41:192-198.

Redpath, S. M. (1995). Habitat fragmentation and the individual: Tawny Owls Strix aluco in woodland patches. Journal of Animal Ecology 64:652-661.

Romanowski, J. and M. Žmihorski (2009). Seasonal and habitat variation in the diet of the Tawny Owl (Strix aluco) in central Poland during unusually warm years. Biologia 64:365-369. 
Rosalino, L. M., D. Ferreira, I. Leitão, and M. Santos-Reis (2011). Selection of nest sites by wood mice Apodemus sylvaticus in a Mediterranean agro-forest landscape. Ecological Research 26:445-452.

Rumbutis, S., D. Vaitkuvienè, G. Grašytè, M. Dagys, D. Dementavičius, and R. Treinys (2017). Adaptive habitat preferences in the Tawny Owl Strix aluco. Bird Study 64:421-430.

Sánchez-Zapata, J. A., and J. F. Calvo (1999). Rocks and trees: Habitat response of Tawny Owls Strix aluco in semiarid landscapes. Ornis Fennica 76:79-87.

Santos, E. S. A., and S. Nakagawa (2012). The costs of parental care: A meta-analysis of the trade-off between parental effort and survival in birds. Journal of Evolutionary Biology 25:1911-1917.

Sasvári, L., and Z. Hegyi (2011). Predation risk of Tawny Owl Strix aluco nests in relation to altitude, breeding experience, breeding density and weather conditions. Ardea 99:227-232.

Senzaki, M., Y. Yamaura, C. D. Francis, and F. Nakamura (2016). Traffic noise reduces foraging efficiency in wild owls. Scientific Reports 6:30602.

Sergio, F., and I. Newton (2003). Occupancy as a measure of territory quality. Journal of Animal Ecology 72:857-865.

Shannon, G., M. F. McKenna, L. M. Angeloni, K. R. Crooks, K. M. Fristrup, E. Brown, K. A. Warner, M. D. Nelson, C. White, J. Briggs, S. McFarland, et al. (2016). A synthesis of two decades of research documenting the effects of noise on wildlife. Biological Reviews 91:982-1005.

Shonfield, J., and E. M. Bayne (2017). The effect of industrial noise on owl occupancy in the boreal forest at multiple spatial scales. Avian Conservation and Ecology 12:13. DOI: 10.5751/ACE-01042-120213.

Silva, C. C., R. Lourenço, S. Godinho, E. Gomes, H. SabinoMarques, D. Medinas, V. Neves, C. Silva, J. E. Rabaça, and A. Mira (2012). Major roads have a negative impact on the Tawny Owl Strix aluco and the Little Owl Athene noctua populations. Acta Ornithologica 47:47-54.

Southern, H. N. (1970). The natural control of a population of Tawny Owls (Strix aluco). Journal of Zoology 162:197-285.

Statsoft, I. N. C. (2007). Statistica. Version, 8, 1984-2004.

Sunde, P., and M. S. Bølstad (2004). A telemetry study of the social organization of a Tawny Owl (Strix aluco) population. Journal of Zoology 263:65-76.

Sunde, P., K. Overskaug, and J. P. Bølstad (2001). Living at the limit: Ecology and behavior of Tawny Owls Strix aluco in a northern edge population in central Norway. Ardea 89:495-508.

Sunde, P., and S. M. Redpath (2006). Combining information from range use and habitat selection: Sex-specific spatial responses to habitat fragmentation in Tawny Owls Strix aluco. Ecography 29:152-158.

Torre, I., and A. Arrizabalaga (2008). Habitat preferences of the bank vole Myodes glareolus in a Mediterranean mountain range. Acta Theriologica 53:241-250.

Trivers, R. L. (1972). Parental investment and sexual selection. In Sexual Selection and the Descent of Man 1871-1971 (B. Campbell, Editor). Aldine, Chicago, IL, USA. pp. 136-179

Vilà, M., J. Vayreda, L. Comas, J. J. Ibáñez, T. Mata, and B. Obón (2007). Species richness and wood production: A positive association in Mediterranean forests. Ecology Letters 10:241-250.

Vrezec, A., and D. Tome (2004a). Habitat selection and patterns of distribution in a hierarchic forest owl guild. Ornis Fennica 81:109-118.

Vrezec, A., and D. Tome (2004b). Altitudinal segregation between Ural Owl Strix uralensis and Tawny Owl Strix aluco: Evidence for competitive exclusion in raptorial birds. Bird Study 51:264-269.

Worthington-Hill, J., and G. Conway (2017). Tawny Owl Strix aluco response to call-broadcasting and implications for survey design. Bird Study 64:205-210.

Zuberogoitia, I. (2011). Weather influence on breeding success of the Tawny Owl on the southwest limit of Eurosiberian Region. In Ecology and Conservation of European Forest-dwelling Raptors (I. Zuberogoitia and J. E. Martínez, Editors). Diputación Foral de Bizkaia, Bilbao, Spain. pp 184-189.

Zuberogoitia, I., G. Burgos, J. A. González-Oreja, J. Morant, J. E. Martínez, and J. Zabala Albizua (2019). Factors affecting spontaneous vocal activity of Tawny Owls Strix aluco and implications for surveying large areas. Ibis 161:495-503.

Zuberogoitia, I., and L. F. Campos (1998). Censusing owls in large areas: A comparison between methods. Ardeola 45:47-53.

Zuberogoitia, I., and J. A. Martínez (2000). Methods for surveying Tawny Owl Strix aluco populations in large areas. Biota 1:79-88.

Received 18 February 2020; accepted 21 April 2020 